\title{
Lithium Induced Toxicity Profile of Oxygen Consumption, Haematological Parameters and Biochemical Profiles of Channa punctatus and Oreochromis niloticus
}

\author{
S. ThangaMalathi and V.Anuradha $\dagger$ \\ Department of Biochemistry, Mohamed Sathak College of Arts and Science, Sholinganallur, \\ Chennai-600119, Tamilnadu, India \\ $\dagger$ Corresponding author: V. Anuradha; vanuradha.2003@gmail.com
}

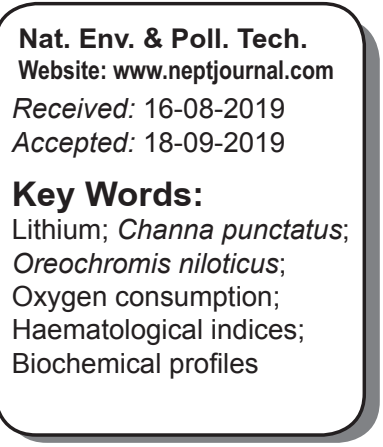

Nat. Env. \& Poll. Tech. Website: www neptjournal.com

Received: 16-08-

\section{Key Words:}

Lithium; Channa punctatus; Oxis niloticus; Haematological indices Biochemical profiles

\begin{abstract}
Freshwaters are highly vulnerable to pollution since they act as immediate sinks for the consequences of human activity always associated with the danger of accidental discharges. Heavy metals constitute a core group of aquatic pollutants and additional concentrations of these metals accumulate in the aquatic ecosystems as a result of land-based activities. Fish mostly tend to bioaccumulate heavy metals, and humans can be at great risk, sometimes even lethal, through contamination of the food chain. An attempt has been made in the present investigation to determine the acute toxicity of lithium and its toxicological effects on survival, physiological, haematological and biochemical parameters of the widely consumed spotted sneak head Channa punctatus and Nile Tilapia Oreochromis niloticus. Short-term acute toxicity tests were performed by exposing the test species to different concentrations of lithium chloride. The results showed that the normal respiratory activity of the fish was significantly affected and there was a depression in the metabolic rate at the end of 24, 48, 72 and 96h exposure. Appreciable decline changes occur in haematological parameters and biochemical profiles of the fish. This study reflects the extent of the toxic effects of lithium and the metal-induced cumulative deleterious effects at various functional levels in the widely consumed freshwater fish, Channa punctatus and Oreochromis niloticus.
\end{abstract}

\section{INTRODUCTION}

Aquatic pollution has become a global problem in recent years. Extensive industrialization has measurably influenced the quality of water lakes, ponds and rivers all over the world. Heavy metals are recognized as one of the most hazardous environmental pollutants and toxic to many organisms. The natural aquatic systems may extensively contaminate with heavy metals released from domestic, industrial and other man-made activities (Vutukuru 2003). Heavy metal contamination may have devastating effects on the ecological balance of the recipient environment and a diversity of aquatic organisms (Ashraj 2005). Among animal species, fishes are inhabitants that cannot escape from the detrimental effects of these pollutants. Heavy metals at high concentrations can cause hazardous effects to metabolic, physiological and biochemical systems of fishes (Heath 1987). Fishes are widely used to evaluate the health of aquatic ecosystems because the pollutants build up in the food chain and are responsible for adverse effects and death in the aquatic ecosystems. Fish respond sensitivity to an increased concentration of contaminants (metals, organic pollutants) in water. The accumulation levels of metals in organs and tissues of fish depend upon taxonomic belonging of fish species, age patterns, their physical-biochemical characteristics and chemical status of the environment they live. Biochemical profiles in fish and other aquatic organisms under heavy metal stress serves as an important bio-indicators in the monitoring of aquatic environment (Ambrose et al. 1994, Vutukuru et al. 2000, Sornaraj et al. 1995, Abbasi et al. 1995, Kszos et al. 2003 and Smithberg \& Dixit 1982). Blood chemistry indices including enzymes, nutrients, metabolites, waste products and inorganic ions have been used to detect cellular damage and measure the responses to metals (O'Neil et al. 1998 and Congleton \& La Voie 2001). The present study aims to investigate the responses of serum biochemical parameters, including haematological indices, enzymes, ions $\left(\mathrm{Na}^{+}, \mathrm{K}^{+}\right.$ and $\mathrm{Cl}^{-}$) and oxygen consumption in $C$. punctatus and $O$. niloticus exposed to lithium metal. Lithium is the lightest metal, in its elemental form, and is highly reactive as a pure element. Because of its reactivity, Li does not occur naturally as a pure element. It occurs instead in stable minerals and salts. It is the $27^{\text {th }}$ most abundant element in nature. Lithium is widely used in ceramics, glass and aluminium production and has some applications for synthetic rubber, pharmaceuticals, chemical manufacturing, lubricants, batteries and 
nuclear reactor coolant and air treatment (Kszos et al. 2003). Since 2007, the most important and the fastest growing area of lithium consumption is the lithium-containing batteries. These are extensively used in small electronic devices like cellular phones, cameras, watches, signal devices as well as laptops. Lithium batteries are increasingly substituting other batteries, so their consumption is constantly expanding (Lenntech 2007). Knowledge of acute toxicity of a xenobiotic often can be very helpful in predicting and preventing acute damage to aquatic life in receiving waters as well as in regulating aquatic toxic waste discharges (Scrosati \& Garche 2010). Because of this, short-term acute toxicity tests were performed on Channa punctatus and Oreochromis niloticusfor $96 \mathrm{~h}$ to determine the $\mathrm{LC}_{50}$ value to elucidate the acute effects of lithium on the survival, oxygen consumption, haematological parameters (Hb, MCHC, MCV, WBC, HCT and $\mathrm{MCH}$ ), enzymes (SGOT, SGPT, ACP and ALP) and some biochemical constituents (total protein, triglyceride, cholesterol, phospholipid, free fatty acid and carbohydrate) of the fishes.

\section{MATERIALS AND METHODS}

Determination of $\mathbf{L C}_{\mathbf{5 0}}$ : Laboratory bioassays were conducted to determine the $24 \mathrm{hr}, 48 \mathrm{hr}, 72 \mathrm{hr}$ and $96 \mathrm{hrs} \mathrm{LC}_{50}$ values for C.punctatus and O.niloticus exposed to lithium chloride. The experimental design and calculations for the acute toxicity procedures were followed as given by Finney (1971).

Acute toxicity tests: The freshwater healthy fish, Channa punctatus and Oreochromis niloticus of the weight $(2 \pm$ $0.84 \mathrm{~g}$ and $1.5 \pm 0.53 \mathrm{~g})$ and length $(15.67 \pm 3.14 \mathrm{~cm}$ and $16 \pm 2 \mathrm{~cm}$ ) were selected for the toxicity tests and samples were collected from Pothur (Thirumullaivoyal) Chennai. Healthy fishes were then transferred to glass aquaria containing unchlorinated groundwater before they were used for experiments. The fishes were acclimated in the laboratory condition for 30days. The feeding and maintenance of the fish and the physico-chemical characteristics of the water used for acclimation, controls and experiments are followed as per the report given earlier (Lenntech 2007). Short-term tests of acute toxicity for $96 \mathrm{~h}$ were performed on the fish following renewal bioassay. Only fishes which were healthy and showed active movements were used for the tests. The desired concentration of lithium chloride anhydrous (SRL pure, Maharashtra, India) was prepared by adding aliquots of $1 \%$ stock solution in double-distilled water. The toxicant solution in the test chambers was replaced with a fresh solution of the same concentration every 24 hours. Renewal bioassays were using following concentrations of lithium chloride viz., $80 \mathrm{mg} / \mathrm{L}$, to $300 \mathrm{mg} / \mathrm{L}$ which resulted in mortality of the fish within the range of 5 to $95 \%$. Ten fishes (both species) were tested at each concentration and the loading was at the recommended level (Sastry \& Sunitha 1984). Controls (both species) without toxicants were also run simultaneously. The behaviour and condition of the fishes were noted every $24 \mathrm{~h}$ up to $96 \mathrm{~h}$. Between the experiments, the test chambers (15-litre capacity) were carefully washed to eliminate residual metal adsorption to the walls. No differentiation was made between sexes.

Statistical analyses: The experiments were repeated thrice and only the arithmetic mean of the three experiments at each concentration was taken to express the results. Probit analysis a log dose against (mortality) was performed adopting standard protocol (Finney 1953).

Oxygen consumption: Since respiratory distress is one of the important manifestations of acute heavy metal toxicity and is known to produce physiological imbalance, Channa punctatus and Oreochromis niloticus were exposed to lithium duration of the period $96 \mathrm{hr}$. In the present study, the respiration rate of the same fish was measured from $24 \mathrm{~h}$ to $96 \mathrm{~h}$ with a $24 \mathrm{~h}$ interval. At the end of $24 \mathrm{~h}$ exposure, each fish was transferred from the test chamber (5l capacity) to respiratory chamber of 1-litre capacity, which is also numbered in accordance with the test chamber. The fish were allowed to stabilize for five minutes and then the experiment was run for a period of $1 \mathrm{~h}$. Only one fish was introduced into each aquarium and a thick layer of coconut oil was spread on the surface (care was taken to avoid trapping air bubbles) of the fish medium to prevent the contact of the medium to the atmosphere and to prevent the fish from reaching the atmospheric air. After the experiment, the fishes were replaced in their test chambers. The same procedure repeated for $48 \mathrm{~h}, 72 \mathrm{~h}$ and $96 \mathrm{~h}$. Any dead fish during the experiment was removed and the test repeated to get the response of at least three fishes. Controls were also run simultaneously to obtain information on the oxygen consumption of the fish in the normal state. Respiratory measurements were made by the method adopted by Fitch (APHA, AWWA, WPCP 1998) and the dissolved oxygen was estimated adopting Winkler's method. All the rate of oxygen consumption per gram weight of the fish per hour was calculated and the values were expressed as $\mathrm{mL} \mathrm{O}_{2} / \mathrm{gm} /$ hour. The respiratory measurements were made in diffused daylight and the time of the experiment was kept constant (11.00am to $3.00 \mathrm{pm})$ to avoid the effect of time of day on the respiration of the fish. The temperature and $\mathrm{pH}$ during experiments were $26.15^{\circ} \mathrm{C}$ $\pm 0.59^{\circ} \mathrm{C}$ and $7.4 \pm 0.21$, respectively.

Haematological studies: Twenty fishes (in both the species, Channa punctatus and Oreochromis niloticus) were used in this investigation. The fish were maintained in the aquaria 
Table 1: Standard methods for the haematological analysis.

\begin{tabular}{|lll|}
\hline Parameters & Methods & References \\
\hline $\mathrm{RBC}$ count $\left(10^{6} / \mathrm{mm}^{3}\right)$ & Haemocytometrically with Neubauer chamber & Davidson et al. (1969) \\
$\mathrm{Hb}(\mathrm{g} \%)$ & Cyanmethaemoglobin method & Drabkins (2010) \\
$\mathrm{WBC}$ count $\left(10^{3} / \mathrm{mm}^{3}\right)$ & Neubauer counting chamber & Donald \& Bonford (1963) \\
$\mathrm{HCT}(\%)$ & Haematocrit method & Schalm et al. (1975) \\
\hline
\end{tabular}

at room temperature $27 \pm 2^{\circ} \mathrm{C}$. The fish were introduced into 10 -litre capacity containers of water containing specific heavy metal lithium. After the recovery period, all such treated fishes were separated from the experimental containers and blood samples were collected from five experimental individuals from each group at each time with an interval of $24 \mathrm{hrs}$ during the experiment. Fish was collected and gently wiped with a dry cloth to remove water. Caudal peduncle was cut with a sharp blade and the blood was collected in small vials (anticoagulated with $0.02 \mathrm{~mL}$ of $10 \%$ EDTA). All the haematological analysis was performed using standard techniques mentioned in Table 1.

Determination of mean corpuscular volume (MCV): $\mathrm{MCV}$ indicates the average size of the blood cell in a given sample of blood. MCV was calculated by the following formula and expressed as femtoliter (fL)

$$
\mathrm{MCV}=\text { Haematocrit }(\%) \times 10 / \mathrm{RBC} \text { count }
$$

Determination of mean corpuscular haemoglobin (MCH): $\mathrm{MCH}$ represents the average content of the $\mathrm{Hb}$ in each red blood cell. MCH is influenced by the Hb concentration and the number of RBC. MCH was calculated by the following formula and expressed in pictogram $(\mathrm{pg})$.

$\mathrm{MCH}=$ Haemoglobin $(\mathrm{g} / \mathrm{dl}) \times 10 / \mathrm{RBC}$ count

Determination of mean corpuscular haemoglobin concentration (MCHC): MCHC reflects the average concentration of the haemoglobin in the red blood cells in the blood. MCHC was obtained by the following formula and expressed in terms of gram percentage $(\mathrm{g} \%)$.

$$
\mathrm{MCHC}=\text { haemoglobin }(\mathrm{g} / \mathrm{dl}) \times 100 / \mathrm{Hb}(\%)
$$

Collection of blood and tissues for the assay: Blood samples were collected in small vials by heart puncture using plastic disposable syringes fitted with prechilled and heparinized 26gauge needle. The blood sample was centrifuged at $10000 \mathrm{rpm}$ for 20 minutes to separate the serum. Simultaneously liver and tissue were excised and homogenized in ice-cold $0.25 \mathrm{M}$ sucrose buffer, $\mathrm{pH} 7.4$. The homogenate was centrifuged at $5000 \mathrm{rpm}$ for 15 minutes at $4^{\circ} \mathrm{C}$. The tissue supernatant, as well as serum, was further used for measurement of following biochemical parameters.

Biochemical studies: The activities of SGPT (ALT), SGOT (AST), ALP and ACP and the concentration of total protein, phospholipid, free fatty acid, triglyceride, carbohydrate and cholesterol, and ions $\left(\mathrm{Na}^{+}, \mathrm{K}^{+}, \mathrm{Cl}^{-}\right)$in the serum and tissues were calculated by using the methods shown in Table 2 .

SGPT and SGOT activities were measured by using the method of Bergmeyer et al (1985); King and Armstrong method for ALP activity; Tenniswood et al. (1976), for ACP activity; Tietz \& Logan (1987), for the electrolytes $\left(\mathrm{Na}^{+}, \mathrm{K}^{+}, \mathrm{Cl}^{-}\right)$.

\section{RESULTS AND DISCUSSION}

Survival: The concentration of lithium chloride tested (Channa punctatus and Oreochromis niloticus) in the present study were $80 \mathrm{mg} / \mathrm{L}$ ( $\mathrm{Li}$ as $0.29 \mathrm{mg} / \mathrm{L}$ and $0.22 \mathrm{mg} / \mathrm{L}$ ), $100 \mathrm{mg} / \mathrm{L}$ ( $\mathrm{Li}$ as $0.32 \mathrm{mg} / \mathrm{L}$ and $0.42 \mathrm{mg} / \mathrm{L}), 120 \mathrm{mg} / \mathrm{L}$ ( $\mathrm{Li}$ as $0.53 \mathrm{mg} / \mathrm{L}$ and $0.44 \mathrm{mg} / \mathrm{L}$ ) and $150 \mathrm{mg} / \mathrm{L}(\mathrm{Li}$ as $0.61 \mathrm{mg} / \mathrm{L}$ and $0.13 \mathrm{mg} / \mathrm{L}$ ). The mortality ranged from $10 \%$ to $95 \%$ and increased with a corresponding increase in the toxicant con-

Table 2: Biochemical studies.

\begin{tabular}{|ll|}
\hline Parameters & Methods \\
\hline Estimation of carbohydrate & GOD - POD method \\
Estimation of cholesterol & Zak's method \\
Estimation of triglyceride & Foster \& Dunn's method \\
Estimation of free fatty acid & Hron \& Menahan method \\
Estimation of protein & Lowry's method \\
Estimation of phospholipid & Folch method \\
\hline
\end{tabular}


Table 3: Changes in the oxygen uptake of Channa punctatus and Oreochromis niloticus at following an exposure period of lithium $\left(\mathrm{O}_{2} \mathrm{~mL} / \mathrm{g} / \mathrm{hr}\right)$.

\begin{tabular}{|lllll|}
\hline \multirow{2}{*}{ Period of exposure } & \multicolumn{3}{l}{ Control X $\pm \mathrm{SD}$} & \multicolumn{2}{l|}{ Experiment X $\pm \mathrm{SD}$} \\
\cline { 2 - 5 } & Channa punctatus & Oreochromis niloticus & Channa punctatus & Oreochromis niloticus \\
\hline $24 \mathrm{~h}$ & $3.98 \pm 0.16$ & $3.52 \pm 0.36$ & $3.31 \pm 0.14$ & $2.48 \pm 0.27$ \\
$48 \mathrm{~h}$ & & $2.50 \pm 0.35$ & $2.03 \pm 0.08$ \\
$72 \mathrm{~h}$ & & $1.94 \pm 0.08$ & $1.41 \pm 0.29$ \\
$96 \mathrm{~h}$ & & $2.00 \pm 0.44$ & $0.85 \pm 0.12$ \\
\hline
\end{tabular}

Values are mean $\pm \mathrm{SD},-$ or + indicate percent decrease or increase over control.

centration and also duration of the exposure demonstrating both time and concentration dependent responses.

\section{Behavioural Manifestations}

The behaviour and condition of the fishes in both the control and test solution were noted every $24 \mathrm{~h}$ up to $96 \mathrm{~h}$. The fishes showed a marked change in their behaviour when exposed to different concentrations of the test solution. Behavioural manifestations of acute toxicity like copious secretion of mucus, loss of scales, discolouration, surfacing and darting movements were observed in Channa punctatus and Oreochromis niloticus exposed to higher concentrations of lithium chloride viz., $80 \mathrm{mg} / \mathrm{L}$ to $150 \mathrm{mg} / \mathrm{L}$ from $24 \mathrm{~h}$ to 96h. The reaction and survival of aquatic animals depend on not only the biological state of the animals and physico-chemical characteristics of water, but also on kind, toxicity, type and time of exposure to the toxicant. Behavioural manifestations of acute toxicity of chromium in Labeo rohita was more or less similar to those reported in other fishes (Mukherjee 1988). Fishes may be attributed to the fact that metal-induced changes in physiology and survival of aquatic organisms under metallic stress are complicated because such changes differ from metal to metal, species to species and from one experimental condition to another. The exact causes of death due to heavy metal poisoning are multiple and depend mainly on time-concentration combinations. However, there is no clear-cut explanation on the exact mode of action of different metals causing the mortality in aquatic animals.

Oxygen consumption: The mean metabolic rates of the control and exposed fishes at the end of $24 \mathrm{~h}, 48 \mathrm{~h}, 72 \mathrm{~h}$ and $96 \mathrm{~h}$ along with the percent decrease from control are given (Table 3). It is clear from the results that the metabolic rate of Channa punctatus and Oreochromis niloticus exposed to lithium decreased from control with the exposure period $24 \mathrm{~h}$ to $96 \mathrm{~h}$. The action of heavy metals on the respiratory function of fishes appears to be diversified. Alterations in the cellular components isa cause of depression in the respiratory activity of fishes exposed to acute metallic stress has been suggested (Pondey et al. 1963). Inhibition of the respiratory enzymes in fishes exposed to heavy metals was also reported (Lowry et al. 1951).

A perusal of the available information reveals that heavy metal-induced alterations in the respiratory function of fishes differ not only from metal to metal but also the sites of action. The decrease in the oxygen consumption of Channa punctatus and Oreochromis niloticus exposed to lithium indicates the onset of acute hypoxia under metallic stress. Further, the fact that the drop in metabolic rate of the fish as a protective measure to ensure that there is a low intake of the toxic substance also cannot be ruled out. Gills are vital respiratory and osmoregulatory organs and cellular damage induced by the metal might impair the respiratory function of the fish by reducing the respiratory surface area (Taylor et al. 1985). These findings suggest decreased respiratory surface area can also account for the drop in the metabolic rate of the fish.

Haematological studies: The present study reveals that the Channa punctatus and Oreochromis niloticus exposed to lithium exhibited a significant increase in their $\mathrm{RBC}, \mathrm{Hb}$, HCT, MCH, MCV, MCHC and WBC compared to control are given in Table 4 and Table 5. The reason for increased haematological values indicates macrocytic type of anaemia. The previous study shows that high level of RBC was recorded in $L$. calcarifer followed by $C$. chanes. The high erythrocyte number was associated with fast movement, predaceous nature and high activity (Rambhaskar \& Srinvasa Rao 1986). The elevated RBC counts and Hb concentrations were recorded in lithium exposed $C$. punctatus and O. niloticus. This elevated level is responsible for the high metabolic demand. The increased level of RBC indicates oxygen demand in the tropical region to meet the higher oxygen requirement at high metabolic rates (Engel \& Davis 1964). Hb value in the present study shows that $19.25 \pm 0.30$ (96hr, C. punctatus) and $19.52 \pm 0.32$ (96hr, O. niloticus) respectively. $\mathrm{RBC} \& \mathrm{Hb}$ concentrations tend to increase with length and age of the fishes (Das 1965). Blaxhall \& Daisley (1973), have reported the possibility of using HCT as a tool in the aquaculture and fishery management for checking the anaemic condition. HCT value in the present study was 
within the range $35.33 \pm 3.05$ ( $96 \mathrm{hr}$, C. punctatus) and 22.34 \pm 1.53 (72hr, O. niloticus) respectively; fish HCT values were usually between $20 \%$ and $35 \%$ and rarely attain greater than 50\% (Clark et al. 1976). Besides, high leukocyte values depend on stress factors resulted in regulatory effects of toxic substances on the immune system. High RBC count perhaps lessens the requirement for a large number of WBC (Xiaoyun et al. 2009). From the results (Table $4 \& 5$ ) shows that the increased amount of $\mathrm{MCV}, \mathrm{MCH}$ and $\mathrm{MCHC}$ observed in $C$. punctatus and $O$. niloticus indicates the microcytic anaemia. This study indicates that changes in haematological parameters in fish serves as an effective tool in the diagnosis of the extent of environmental pollution and also the abiotic fish diseases. Increased in total WBC count in the present study was a result of direct stimulation for its defence from diseases due to the presence of heavy metals. Increase in WBC count as in the present study was also reported by Murugesen \& Haniffa (1985), in heavy metal treated fish blood, suggesting induction of some pathology and also might be due to the effect of metal toxicants on bone marrow. Leucocytosis has been considered to be an adaptation to meet stressful conditions by aquatic species.

Haematological parameters are very important parameters for the evaluation of fish physiological status under metabolic stress. From the results, (Table 4 \& Table 5) clearly shows that the changes in blood indices and their peculiarities depend on the concentration of heavy metals and duration of exposure of fish to them. In the present study, the anaemia could be probably due to structural alterations of heme leading to disturbed haemoglobin synthesis and also the inhibitory effect of lithium on the enzyme system in the synthesis of haemoglobin cannot be ruled out as suggested in earlier studies (Vincent et al. 1996).

Biochemical studies: The carbohydrate, phospholipid, total protein, cholesterol, triglyceride and free fatty acid levels in liver, muscle and blood of control fish and exposed fish of Channa punctatus and Oreochromis niloticus to the $96 \mathrm{hr}$ concentration of Lithium are represented in Table 6. It is clear from the results that there is an appropriate decline in different biochemical constituents of the fish under lithium stress.

The ranges of biochemical parameters vary from species to species and can be influenced by many biotic and abiotic factors such as water, temperature, seasonal pattern, food age and sex of the fish (Jawad et al. 2004). In the present investigation increased level of biochemical profiles (Carbohydrate, Protein, Phospholipid, Triglyceride, Free fatty acid and Cholesterol) increased in the liver and muscle tissues compared to the blood sample in C.Punctatus and

Table 4: Haematological parameters of Channa punctatus on exposure to Lithium.

\begin{tabular}{|c|c|c|c|c|c|}
\hline Parameters & Normal & 24 & 48 & 72 & 96 \\
\hline $\operatorname{RBC}\left(10^{6} / \mathrm{mm}^{3}\right)$ & $4.08 \pm 0.49$ & $8.82 \pm 0.27$ & $8.54 \pm 0.21$ & $9.10 \pm 0.11$ & $8.99 \pm 0.24$ \\
\hline $\mathrm{Hb}(\mathrm{g} \%)$ & $10.78 \pm 0.54$ & $14.62 \pm 1.02$ & $16.71 \pm 1.18$ & $18.93 \pm 0.25$ & $19.25 \pm 0.30$ \\
\hline WBC $\left(10^{3} / \mathrm{mm}^{3}\right)$ & $5.18 \pm 0.17$ & $5.09 \pm 0.09$ & $5.56 \pm 0.51$ & $6.23 \pm 0.66$ & $7.28 \pm 0.51$ \\
\hline $\operatorname{HCT}(\%)$ & $19.2 \pm 1.66$ & $26 \pm 2$ & $30.33 \pm 3.05$ & $32.67 \pm 3.00$ & $35.33 \pm 3.05$ \\
\hline MCV (fL) & $168.66 \pm 0.98$ & $183.28 \pm 4.86$ & $184.04 \pm 1.85$ & $189.57 \pm 0.99$ & $193.66 \pm 5.48$ \\
\hline $\mathrm{MCH}(\mathrm{pg})$ & $46.3 \pm 1.97$ & $66.03 \pm 1.92$ & $63.42 \pm 4.11$ & $70.28 \pm 1.06$ & $71.29 \pm 0.86$ \\
\hline $\mathrm{MCHC}(\mathrm{g} \%)$ & $7.14 \pm 0.59$ & $9.99 \pm 0.10$ & $11.2 \pm 0.25$ & $12.67 \pm 0.49$ & $14.83 \pm 0.38$ \\
\hline
\end{tabular}

Values are mean $\pm \mathrm{SD},-$ or + indicate percent decrease or increase over control.

Table 5: Haematological parameters of Oreochromis niloticus on exposure to Lithium.

\begin{tabular}{|llllll|}
\hline Parameters & Normal & 24 & 48 & 72 & 96 \\
\hline RBC $\left(10^{6} / \mathrm{mm}^{3}\right)$ & $4.84 \pm 0.13$ & $6.78 \pm 0.22$ & $7.98 \pm 0.14$ & $8.52 \pm 0.35$ & $19.09 \pm 0.10$ \\
Hb $(\mathrm{g} \%)$ & $10.3 \pm 0.17$ & $18.59 \pm 0.54$ & $18.29 \pm 0.58$ & $7.39 \pm 0.27$ & $19.52 \pm 0.32$ \\
WBC $\left(10^{3} / \mathrm{mm}^{3}\right)$ & $6.13 \pm 0.25$ & $6.49 \pm 0.45$ & $7.51 \pm 0.30$ & $7.68 \pm 0.50$ & $8.45 \pm 0.05$ \\
HCT $(\%)$ & $15.23 \pm 0.49$ & $21.67 \pm 1.53$ & $19.67 \pm 2.08$ & $22.34 \pm 1.53$ & $21.00 \pm 1.00$ \\
MCV (fL) & $195.29 \pm 4.09$ & $200.67 \pm 0.48$ & $210.43 \pm 0.58$ & $216.73 \pm 2.34$ & $222.34 \pm 2.30$ \\
MCH $(\mathrm{pg})$ & $33.11 \pm 0.96$ & $63.91 \pm 2.18$ & $68.7 \pm 2.08$ & $70.25 \pm 0.98$ & $76.11 \pm 3.15$ \\
MCHC $(\mathrm{g} \%)$ & $19.10 \pm 2.03$ & $21.78 \pm 1.44$ & $25.42 \pm 0.93$ & $27.33 \pm 1.08$ & $25.55 \pm 3.10$ \\
\hline
\end{tabular}

Values are mean $\pm \mathrm{SD},-$ or + indicate percent decrease or increase over control. 
O.Niloticus. An increased level of carbohydrate and protein level was recorded in C.punctatus and O.niloticus, this may be caused due to an increased depletion of liver glycogen (Ojolick et al. 1995). The increased protein concentration can be caused by structural liver alterations (Kavadias et al. 2004). Carbohydrate concentration increased significantly in $\mathrm{Li}$ exposed fish when compared to control group (Table 6). Alterations in the glucose level might be related to renal injury, liver damage, and lack of nutrition (Canli 1995). Increased level of total protein concentration in Channa punctatus and Oreochromis niloticus indicates liver damage, reduced absorption and protein loss. Increased level of triglyceride recorded (muscle $>$ liver $>$ blood) in both the species compared to control. Canli (1995), showed that serum triglyceride levels in C.carpio exposed to Ga increased considerably compared to the control. Triglyceride concentration is important to evaluate lipid metabolism and higher levels may occur with nephritic syndrome and glycogen storage impairment. Triglyceride functions primarily in providing cellular energy and can be used as an indicator of nutritional status. Increased level of cholesterol concentration in metal exposed fish compared to control fish. The concentration of cholesterol, an essential structural component of membranes and the precursor of all steroid hormones, may increase due to the liver and kidney failure causing the release of cholesterol into the blood. Elevation of phospholipid and free fatty acid

Table 6: Levels of biochemical parameters in blood, liver and tissue of Channa punctatus and Oreochromis niloticus on exposed to Lithium (mg/dL).

\begin{tabular}{|llllllll|}
\hline Parameters & \multicolumn{3}{c}{ Channa punctatus } \\
\cline { 2 - 7 } & & Blood & Liver & Tissue & Blood & Liver \\
\hline Total Protein & Normal & $7.78 \pm 0.55$ & $7.35 \pm 0.54$ & $8.73 \pm 0.55$ & $9.59 \pm 0.41$ & $10.35 \pm 0.36$ & $11.32 \pm 0.51$ \\
& Treated & $13.52 \pm 0.53$ & $19.08 \pm 0.51$ & $20.70 \pm 1.20$ & $28.76 \pm 0.81$ & $27.73 \pm 0.86$ & $27.88 \pm 1.43$ \\
Carbohydrate & Normal & $66.81 \pm 0.99$ & $71.31 \pm 2.58$ & $74.24 \pm 4.23$ & $84.18 \pm 1.74$ & $89.05 \pm 1.00$ & $94.12 \pm 5.20$ \\
& Treated & $97.39 \pm 3.10$ & $125.88 \pm 2.75$ & $134.1 \pm 6.76$ & $142.17 \pm 3.09$ & $159.18 \pm 6.43$ & $153.93 \pm 5.36$ \\
Phospholipids & Normal & $3.07 \pm 0.25$ & $2.73 \pm 0.21$ & $2.03 \pm 0.05$ & $7.27 \pm 0.47$ & $8.10 \pm 0.56$ & $7.24 \pm 0.60$ \\
& Treated & $3.5 \pm 0.36$ & $4.13 \pm 0.65$ & $5.16 \pm 1.10$ & $9 \pm 0.7$ & $11.56 \pm 0.58$ & $12.2 \pm 1.25$ \\
Free Fatty & Normal & $52.19 \pm 0.93$ & $51.57 \pm 0.54$ & $49.08 \pm 0.92$ & $62.76 \pm 0.52$ & $65.88 \pm 0.77$ & $68.75 \pm 0.57$ \\
Acids & Treated & $49.05 \pm 0.96$ & $60.33 \pm 0.66$ & $61.35 \pm 1.65$ & $56.86 \pm 1.74$ & $64 \pm 2.01$ & $70.99 \pm 1.05$ \\
Triglycerides & Normal & $16.34 \pm 1.46$ & $18.69 \pm 0.46$ & $19.91 \pm 0.13$ & $27.39 \pm 2.05$ & $32.21 \pm 1.59$ & $33.80 \pm 2.53$ \\
& Treated & $30.54 \pm 0.78$ & $30.76 \pm 1.07$ & $31.64 \pm 1.59$ & $41.51 \pm 0.62$ & $47.21 \pm 0.55$ & $56.05 \pm 4.73$ \\
Cholesterol & Normal & $213.07 \pm 3.52$ & $229.76 \pm 10.49$ & $211.62 \pm 9.44$ & $182.66 \pm 1.84$ & $179.38 \pm 1.44$ & $189.10 \pm 9.55$ \\
& Treated & $154.96 \pm 4.51$ & $159.88 \pm 10.10$ & $167.31 \pm 5.10$ & $219.30 \pm 5.99$ & $222.18 \pm 3.38$ & $266.10 \pm 37.38$ \\
\hline
\end{tabular}

Values are mean $\pm \mathrm{SD},-$ or + indicate percent decrease or increase over control.

Table 7: Levels of enzyme parameters in blood, liver and tissue of Channa punctatus and Oreochromis niloticus exposed to Lithium (IU/L).

\begin{tabular}{|llllllcc|}
\hline Parameters & & \multicolumn{3}{c|}{ Channa punctatus } \\
\cline { 3 - 7 } & & Blood & Liver & Tissue & Blood & Liver \\
\hline SGPT & Normal & $30.17 \pm 1.01$ & $29.57 \pm 1.13$ & $28.65 \pm 1.00$ & $28.67 \pm 0.59$ & $29.4 \pm 0.4$ & $30.33 \pm 0.76$ \\
& Treated & $29.93 \pm 0.07$ & $36.55 \pm 5.64$ & $21.09 \pm 0.92$ & $36.03 \pm 0.38$ & $48.66 \pm 0.72$ & $40.04 \pm 1.24$ \\
\multirow{2}{*}{ SGOT } & Normal & $18.04 \pm 0.91$ & $19.11 \pm 0.13$ & $18.74 \pm 0.86$ & $15.46 \pm 0.58$ & $16.43 \pm 1.11$ & $16.12 \pm 0.91$ \\
& Treated & $11.86 \pm 1.40$ & $10.54 \pm 1.02$ & $10.12 \pm 1.13$ & $18.43 \pm 1.04$ & $21.85 \pm 1.74$ & $22 \pm 1.69$ \\
ACP & Normal & $31.21 \pm 0.60$ & $31.67 \pm 0.67$ & $30.67 \pm 1.45$ & $36.09 \pm 0.55$ & $34.50 \pm 1.53$ & $33.38 \pm 0.62$ \\
& Treated & $52.55 \pm 1.05$ & $54.9 \pm 1.78$ & $66.88 \pm 0.95$ & $45.45 \pm 1.37$ & $58.90 \pm 1.01$ & $53.46 \pm 3.43$ \\
ALP & Normal & $99.14 \pm 1.00$ & $106.14 \pm 5.32$ & $98.43 \pm 1.44$ & $113.13 \pm 2.79$ & $117.70 \pm 5.01$ & $106.74 \pm 5.03$ \\
& Treated & $145.16 \pm 12.26$ & $142.24 \pm 12.35$ & $148.73 \pm 13.60$ & $165.83 \pm 6.84$ & $155.75 \pm 2.57$ & $131.51 \pm 3.02$ \\
\hline
\end{tabular}

Values are mean \pm SD, - or + indicate percent decrease or increase over control; SGPT - Serum glutamate pyruvate transaminase; SGOT - Serum glutamate oxaloacetate transaminase; ALP - Alkaline phosphatase; ACP - Acid phosphatase 
Table 8: Levels of biochemical parameters in blood, liver and tissue of Channa punctatus and Oreochromis niloticus exposed to lithium (mmol/L).

\begin{tabular}{|llllllll|}
\hline \multirow{2}{*}{ Parameters } & \multicolumn{3}{c}{ Channa punctatus } & \multicolumn{3}{l}{ Oreochromis niloticus } \\
\cline { 2 - 7 } & \multicolumn{3}{c}{ Blood } & Liver & Tissue & Blood & Liver \\
\hline $\mathrm{Na}$ & Normal & $74.77 \pm 4.17$ & $45.71 \pm 2.13$ & $22.07 \pm 1.65$ & $81.01 \pm 1.89$ & $56.66 \pm 3.39$ & $45.07 \pm 2.74$ \\
& Treated & $60.79 \pm 1.45$ & $110.23 \pm 1.95$ & $41.39 \pm 2.17$ & $94.78 \pm 4.49$ & $63.78 \pm 1.52$ & $103.01 \pm 2.32$ \\
$\mathrm{~K}$ & Normal & $6.4 \pm 0.48$ & $5.63 \pm 0.73$ & $4.64 \pm 0.47$ & $2.46 \pm 0.52$ & $1.72 \pm 0.56$ & $0.74 \pm 0.51$ \\
& Treated & $8.86 \pm 0.08$ & $7.54 \pm 0.62$ & $6.73 \pm 0.45$ & $3.72 \pm 0.24$ & $3.28 \pm 0.16$ & $2.65 \pm 0.42$ \\
$\mathrm{Cl}$ & Normal & $92.28 \pm 6.01$ & $82.46 \pm 2.50$ & $64.47 \pm 2.09$ & $103.60 \pm 3.38$ & $94.64 \pm 4.61$ & $98.11 \pm 1.80$ \\
& Treated & $105.53 \pm 2.08$ & $80.79 \pm 1.40$ & $87.67 \pm 1.40$ & $103.01 \pm 2.32$ & $116.59 \pm 5.29$ & $117.58 \pm 2.16$ \\
\hline
\end{tabular}

Values are mean $\pm \mathrm{SD},-$ or + indicate percent decrease or increase over control.

(96hr-both species) in the present study may be attributed to the prevention of tissue damages in the fish. Similarly, Swelium (2006), also reported an increased level of phospholipids in Oreochromis niloticus exposed to the pesticide. In the present study, the elevated level of phospholipid and free fatty acid shows that utilization of lipid for meeting the energy demand under the metal stress.

Transaminases like SGOT and SGPT play a significant role in protein and amino acid metabolism and they may release into the plasma following tissue damage and dysfunction. Increased level of SGOT and SGPT amount shows that damage of tissues and impairment of fish metabolism. Zikic et al. (2001), showed the increased level of AST \& ALT in Cd-exposed fish Carassius auratusgibelio; the author indicated that liberation of these transaminases into the circulation might occur due to damage of the liver, kidney, heart and other tissues in the state of stress influenced by metals. Acid phosphatases are enzymes concerned with the biosynthesis of fibrous proteins and mucopolysaccharides or they may serve as regulators of intracellular phosphatase concentration (Gutman 1959). They are also hydrolytic enzymes which play an active part in the dissolution of the body's dead cells; stimulation or inhibition of these enzymes will thus result in metabolic disturbances (Sanisa et al. 1982). In the present investigation Table 7 shows that the increased level of acid phosphatase level in all the tissues show in both $C$. punctatus and $O$. niloticus species. The elevated level in the acid phosphatase activity in the tissues of metal exposed fish indicates that, disruption of the lysosomal membrane, cytotoxic action and alteration in the membrane stability. Alkaline phosphatase exposed in treated fish compared to control (Table 7). In the previous study, increased ALP activity in the serum and gill in Cyprinus carpio exposed to $\mathrm{Cu}$ (Singh \& Reddy, 1990). Increased level ALP observed in both (C. punctatus and $O$. niloticus) species compared to control fish. The elevated level of metal exposure causes structural changes in the fish.
Table 8, shows that alteration of ion levels occurred in $\mathrm{Li}^{-}$ exposed fish when compared to the control group. Increased level in the order of $C$. punctatus (liver $>$ blood $>$ tissue) and $O$. niloticus (tissue $>$ blood $>$ liver) in sodium. Increased level of potassium in the order of $C$. punctatus (blood $>$ liver $>$ tissue) and O.niloticus (blood>liver>tissue). Increased level of chlorine in the order of C. punctatus (blood $>$ tissue $>$ liver) and $O$. niloticus (tissue $>$ liver $>$ blood). Cerqueira \& Fernandas (2002) also showed that there was a significant decrease in plasma $\mathrm{Na}$ and $\mathrm{Cl}$ levels and an increase in $\mathrm{K}$ level in the serum of Prochilodus scrofa following acute $\mathrm{Cu}$ exposure, indicating gill tissue damage of fish. Alterations in ion levels reflected with an inhibition in the activity of bronchial $\mathrm{Na}$, $\mathrm{K}$ and disruption of ionoregulatory systems. Due to exposure of lithium, it leads to failure of $\mathrm{Na}$ and $\mathrm{Cl}$ regulatory mechanisms. Electrolyte levels are one of the significant biomarkers in ecotoxicology because their levels can be altered sensitively due to reduced bronchial ion extrusion, reduced intestinal fluid absorption and changes in the morphological structure of cells.

\section{SUMMARY}

Blood glucose or carbohydrate is a sensitive tool and reliable indicator of pollutants causing environmental stress in fish. Lithium toxicity possibly associated with changes in liver carbohydrate metabolism which causes activation of liver glycogenolysis and glycolysis as well as increased levels of plasma glucose and lactate. Increased level of total protein, triglyceride, phospholipid, cholesterol (increased in lithium exposed Channa punctatus and decreased in lithium exposed Oreochromis niloticus) and free fatty acid in C.Punctatus and $O$. niloticus exposed to lithium. Lipids are an important fuel reserve of aquatic organisms during stress. The depletion in tissue proteins of $C$. punctatus and $O$. niloticus may be due to impaired protein synthesis under metallic stress or due to their utilization in the formation of mucoproteins, which are eliminated in the form of mucous. Further, direct or indirect 
utilization of proteins and lipids for energy needs was also reported (Janardhana Reddy et al. 1998). Also, the utilization of proteins in cell repair and organization as causes of their depletion in the tissues cannot be ruled out. Cholesterol and phospholipids are generally considered to be structural or functional lipid being incorporated to a large extent in the membrane structure of the cell and subcellular organelles. Cholesterol concentrations in the serum of metal - exposed fish generally increased when compared to that of the control fish in Channa punctatus. The concentration of cholesterol, an essential structural component of membranes and the precursor of all steroid hormones, may increase due to the liver and kidney failure causing the release of cholesterol into the blood. Heavy metals are known to have hazardous effects on cell structure, especially on the membranes. Therefore, increases in cholesterol may be a good indication of environmental stress. Triglyceride concentration is important to evaluate lipid metabolism and higher levels may occur with nephritic syndrome and glycogen storage impairment. Triglyceride functions primarily in providing cellular energy and can be used as an indicator of nutritional status. Enzymes are sensitive tools to analyse the environmental stress indicator. Transaminases like SGOT and SGPT play a significant role in protein and amino acid metabolism and they may release into the plasma following tissue damage and dysfunction. Alkaline phosphatase is a polyfunctional enzyme that acts as transphosphorylase at alkaline $\mathrm{pH}$ and plays an important role in the mineralisation of the skeleton of aquatic animals and in membrane transport activities. ACP is a lysosomal enzyme that hydrolysis organic phosphates at an acid $\mathrm{pH}$. Changes in ALP and ACP activity also could be as a result of physiological and functional alterations in metal exposed fish. Lithium assumed as an ion regulatory toxicant. Water ions $\mathrm{K}$ and $\mathrm{Na}$ play a protective role against $\mathrm{Li}$. Serum ion levels are one of the significant biomarkers in eco-toxicology because their levels can be altered sensitively due to reduced bronchial ion extrusion, reduced intestinal fluid absorption, and changes in the morphological structure of cells. The present study showed that lithium-induced alterations at the biochemical level, more pronounced changes occurring at the end of $96 \mathrm{~h}$ and thus it is time-dependent.

\section{CONCLUSION}

Acute exposure of lithium proved to be highly toxic to Channa punctatus and Oreochromis niloticus and induced cumulative deleterious effects at various vital functional sites like metabolic rate, haematological indices and biochemical profiles. Though significant changes are observed both at the end of $24 \mathrm{~h}$ and $96 \mathrm{~h}$ exposure periods, these changes are more pronounced at the end of 96h suggestive of time-dependent toxicity. The metal-induced decrease in the total protein content could affect the enzyme-mediated bio-defence mechanisms of the fish, which pose a serious threat to human beings by secondary poisoning through the food chain. Haematological and biochemical parameters are valuable tools for monitoring fish health, confirming maturation and monitoring any changes in the quality of water and related soil. The ranges of normal values of the key biochemical parameters are still undefined for different species in different aquaculture conditions. The results of this present investigation indicate the knowledge about lithium toxicity in aquatic ecosystems and also show that haematological and biochemical profiles are sensitive tools to analyse the toxicity studies and significant to show the awareness of the pollution in pisciculture and aquatic environments.

\section{REFERENCES}

Abbasi, S.S., Kunahmed, T., Nipaney, P. C. and Soni, R. 1995. Influence of the acidity on chromium toxicity- a study with the teleost, Nuria danricus as model.Poll. Res., 14(3): 317-323.

Ambrose, T., Cyril Arun Kumar, L., Vincent, S. and Roselyn Lambert 1994. Biochemical responses of Cyprinus carpiocommunis to toxicity of tanneryeffluent. J. Ecobiol. 6(3): 213-216.

APHA, AWWA and WPCP 1998. Standard methods for the examination of Water and Wastewater. 20th ed.American Public Health Association, Washington,DC.

Ashraj, W 2005. Accumulation of heavy metals in kidney and heart tissues of Epinephelusmicrodon fish from the Arabian Gulf. Environ. Monit. Assess., 101 (1-3): 311-316.

Bergmeyer, H.U., Horder, M. and Rej, R. 1985. International federation of clinical chemistry (IFCC) scientific committee. J Clin Chem Clin Biochem 24: 481-495.

Blaxhall, P.C. and Daisley, K.W. 1973. Routine haematological methods for use with fish blood. J. fish biolo 5:771-781.

Canli, M. 1995. Effects of mercury, chromium and nickel on some blood parameters in the carp Cyprinus carpio. Turkish journal of zoology 19: 305-311.

Cerqueira, C.C.C. and Fernandes, M.N. 2002. Gill tissue recovery after copper exposure and blood parameters responses in the tropical fish Prochilodus scrofa. Ecotoxicol Environ saf 52: 83-91.

Clark, S., Whitemore, D.H. and McMahon, R.F. 1976. Consideration of blood parameters of large mouth bass, Micropterus salmoides, J.Fish. Biol 14:147-154.

Congleton, J.L. and La Voie, W.J. 2001. Comparison of blood chemistry values of samples collected from juvenile Chinook salmon by three methods. J Aquat Health 13: 168-172.

Davidson, I., Henry, J.B. and Todd-Sanford 1969. Clinical diagnosis by laboratory methods, edn, 14, p1165.

Das, B.C. 1965. Age related trends in the blood chemistry and haematology of the Indian carp Catlacatla. Geronotologia 10:47-64.

Donald, H. and Bonford Hutchinson, 1963. Clinical methods $14^{\text {th }}$ edition. London. Pp145.

Drabkins , 2010. Practical haematology, 18:90.

Engel, D.M. and Davis, E.M. 1964. Relationship between activity and blood composition in certain marine teleosts, copei 3:586-587.

Finney, D.J. 1953. Probit analysis 2nd edition. CambridgeUniversity press, Cambridge England.

Finney, D.J. 1971. Probit analysis 2nd edition. Cambridge University Press, Cambridge England. 
Fitch, D.D. 1975. Oxygen consumption in the Prosobranch snail, Viviparous contectoides (Mollusca:Gastropoda) - Effects of weight and activity. Comp. Biochem. Physio.1,51A,815-820.

Folch, J., Lees, M. and Sloane-Stanley, G.H. 1957. A simple method for the isolation and purification of total lipids from animal tissues. J.Biol. Chem, 226, 497 - 509.

Foster, L.B. and Dunn, R.T. 1973. Stable reagents for determination of serum of serum triglycerides by colorimetric Hantzsch condensation method. Clin. Chem. 19: 338 - 340.

Gutmann, A.B. 1959. Serum alkaline phosphatase activity in diseases of skeletal and hepatobiliary system. American Journal of medicine. 27:pp875.

Heath, A.G. 1987. Water pollution and fish physiology. CRC, Boca, Raton, FL, USA, pp245.

Hron, W.T. and Menahan, L.A. 1981. A sensitive method for the determination of free fatty acids in plasma. J. Lipid Res. 22: $371-381$.

Janardhana Reddy, S., Kalarani, V., Tharakanadha, B., Reddy, D.C. and Ramamurthi, R. 1998. Changes in energy metabolism of the fish, Labeo rohita in relation to prolonged lead exposure and recovery. J.Ecotoxicol. Environ. Monit.,8 (1): 43-53.

Jawad, L.A., Al-Mukhtal, M.A. and Ahmed, H.K. 2004. The relationship between haematocrit and some biological parameters of the Indian shed, Tenualosailisha (family Clupidae) Animbiodivers, conservation 27:478-483.

Kavadias, S., Castritsi-Catharibs, J. and Dessyprie, A. 2004. Annual cycles of growth rate, feeding rate, food conversion, plasma glucose and plasma lipids in the population of Europian seabass (Dicentrarchuslabrax) farmed J.Appl.Ichthyol 19:29-34.

King, E.J and Armstrong, A.R. 1934. Cannada medical association journal. 31,376 .

Kszos, L.A. Beauchamp, J.J. and Stewer, A.J. 2003. Toxicity of lithium to three freshwater organisms and the antagonistic effect of sodium ecotoxicol 12: 427-437.

Lenntech, 2007. Lithium and water. Reaction mechanisms, environmental impact and health effects.

Lowry, O.H., Rosebrough, N.J., Lewis Farr, A. and Randall, R. 1951. Protein measurement with Folin Phenol Reagent. J. Biol. Chem.193, 265-275.

Mukherjee, K.L. 1988. Medical Laboratory Technology. A procedure manual for routine diagnostics tests, Vol I., Tata-McGraw- Hill, New Delhi, pp. 48.

Murugesen, A.G. and Haniffa, M.A. 1985. Effect of textile mill effluent on haematological changes of the obligatory air breathing fish Anabas Testudineus. Proc. Nat. symp. Asses. Env. Pollut. Pp121-128.

Ojolick, E.J. Cusack, R. Benfey, T.J. and Kerr, S.R. 1995. Survival and growth of all female diploid and triploid Claris macrocephalus. Fish genetics biotro special pub 52:79-86.

O'Neil, M.D. Wesp, H.M. Mensinger, A.F. and Hanlon, R.T. 1998. Initial baseline blood chemistry of the oyster toadfish, Opsanus tau. Biol Bull 195: 228-229.

Pondey, S. V., Khan, A.P. and Subramanyam, T.A.V. 1963. Micro determination of lipids and serum fatty acids. Analyst. Biochem., 6(5): 120-125.

Rambhaskar, B. and Srinivasa Rao, K. 1986. Comparative haematology of ten species of marine fish from Visakhapatnam coast. J fish boil 30:59-66.

Sanisa, P.K., Bedi, R. and Soci, C.I. 1982. Effects of vegetable oil factory effluent on the levels of phosphatises and dehydrogenases in the liver and kidney of the freshwater teleost, Channa punctatus (Bloch). Environmental Pollution Sci., 4(28): 245-253.

Sastry, K.V. and Sunitha, K. 1984. Chronic toxic effects of chromium in Channa punctatus: Biochemical studies. J. Environ. Biol.,5(1): 53-56.

Scrosati, B. and Garche, J. 2010. Lithium batteries: status, prospects and future. J Power Sources 195; 2419-2430.

Schalm, O.W., Jain, N.C. and Carrol, E.J. 1975. Veterinary haematology, $3^{\text {rd }}$ ed., Lea and Febiger, Philadelphia.

Singh, H.S. and Reddy, T.V. 1990. Effect of copper sulfate on haematology, blood chemistry, and hepatosomatic index of an Indian catfish, Heteropneustes fossillis (Bloch), and its recovery. Eco-toxicol environ saf 20:30-35.

Smithberg, M. and Dixit, P.K. 1982. Teratogenic effects of lithium in mice Teratology 26: 239- 246.

Sornaraj, R., Baskaran, P. and Thanalakshmi, S. 1995. Effects of heavy metals on some physiological responses of air breathing fish, Channa punctatus(Bloch). Environmental Ecology 13(1):202-207.

Swelium, M.A. 2006. Effect of sub-lethal toxicity of some pesticides on growth parameters, haematological properties and total production of Nile tilapia and water quality of ponds. Aquacult. Rese., 37: 1079-1089.

Taylor, D. Maddock, B.G. and Mance, G. 1985. The acute toxicity of nine "grey-list' metals (Arsenic, Boron, Chromium, Copper, Lead, Nickel, Tin, Vanadium and Zinc) to two marine fish species, Limandalimandaand Chelonlabrosus. Aquatic. Toxicol.7,136-144.

Tenniswood, M., Bird , C.E. and Clark A.T. 1976. Canadian journal of biochemistry., 54: p350.

Tietz, N.W. and Logan, N.M 1987. Fundamentals of clinical chemistry. WB Saunders, Philadelphia, PA, USA.

Vincent, S., Ambrose, T., Cyril Arun Kumar, L. and Selvanayagan, M. 1996. Heavy metal cadmium influenced anaemia in Catlacatla. J. Environ. Biol.,17(1): 81-84.

Vutukuru, Srinivas, S. and Balaparmeswara, Rao M. 2000. Impact of hexavalent chromium on survival of the frewshwater fish, Sarotherodonmossambicus. J.Aqua. Biol., Vol. 15 (1 and 2): 71-73.

Vutukuru, S.S. 2003. Chromium induced alterations in some biochemical profiles of the Indian major carp, Labeorohita (Hamilton). Bull. Environ. Contam.Toxicol. 70, 118-123.

Winkler, L.W. 1888. Die Bestimmung des in Wasser gelosten Sauerstoffen Berichte der Deutschen Chemischen Gesellschaft. 21: 2843 - 2855.

Xiaoyun, Z., Mingyun, L., Khalid, A. and Weinmin, W. 2009. Comparative of haematology and serum biochemistry of cultured and wild Dojoloach Misgurnusanguilicadatus. Fish physiolbiochem 35:435-441.

Zak, B. and Ressler, N. 1955. Methodology in determination of cholesterol: A review. American Journal of Clinical Pathology, 25(4_ts): 433-446.

Zikic, R.V. Stajn, S. Pavlovic, Z. Ognjanovic, B.I. and Saicic, Z.S. 2001. Activities of superoxide dismutase and catalase in erythrocyte and plasma transaminases of goldfish, exposed to cadmium. Physiol res 50:105-111. 